\title{
SCD Gene
}

National Cancer Institute

\section{Source}

National Cancer Institute. SCD Gene. NCI Thesaurus. Code C102776.

This gene plays a role in fatty acid metabolism. 